\title{
Bulgaristan'ın İvraca ve Rahova Kazalarında Yaşayan Çerkeslerin Nüfus Yapısı ve İktisadi Etkinlikleri (1860-1870)
}

\author{
Margarita Koleva Dobreva*
}

Özet

Rus-Kafkas Savaşı'nın sonuna yaklaşıldığı 1860'lardan itibaren Çarlık Rusyası tarafından Osmanlı topraklarına sürülen Çerkeslerin önemli bir kısmı Balkanlar'a, bunların içinde bir kısmı da bugünkü Bulgaristan topraklarına yerleştirildi. Iuraca (Vratsa) ve Rahova (Oryahovo) kazalarında toplam 19 Çerkes yerleşim yeri bulunuyordu.

Eldeki nüfus verilere göre göçmen Çerkes ailelerinde ortalama nüfus 3.3 kişiyken, 8 kişilik ailelere de rastlanıyordu. Ailelerin çoğu 2 çocuğa sahipti, 4-5 çocuklu aileler ise istisnaydı. Hem kız ve erkek çocuk, hem de kadın ve erkek sayıları arasında nedenleri tespit edilemeyen önemli bir oransızlık görülüyordu.

Ovalık Rahova kazasından farklı olarak ivraca kazası dağlık ve toprakları taşılılıydı, tarıma elverişli değildi. Dolayısıyla ivraca kazasına daha çok hayvancılıkla geçinen Çerkesler yerleştirilirken Rahova'dakilerin önemli kısmı günlük işlerde çalışıordu. Çerkesler, tarım arazilerinin büyüklüğü açısından önemli sorunlar yaşamadılar. Elde ettikleri ürünün miktarını doğal afetler, toprağın kalitesi, mevcut iş gücü, istek ve ihtiyaç gibi faktörler belirliyordu. Muhtemelen Rahova kazasındaki Çerkes ailelerinin çoğu, 4 kişilik bir ailenin yıllık gıda ihtiyacını karşılayabiliyordu. Bazıları ürünlerini bir kısmını yerel pazarda satabiliyordu. Bu nedenle Çerkes aileleri, tüm köylüler gibi hasat ettikleri ürüne bağımlıydılar.

1877-1878 Osmanlı - Rus Savaşı'nın sonuna kadar bölgede yaşamaya devam eden Çerkesler, savaş sırasında Bulgaristan'daki yerlerini terk etmek zorunda kaldılar ve imparatorluğun Anadolu ve Ortadoğu'daki topraklarına yerleştiler. Böylece Bulgaristan'daki Çerkes varlığı sona ermiş oldu.

Anahtar Kelimeler: Çerkesler, sürgün, Bulgaristan, nüfus, akrabalık, tarım, hayvancilık

Yrd. Doç. Dr., Bulgaristan Bilimler Akademisi, Balkan Araştırmaları Enstitüsü, Sofya, Bulgaristan 
Demographic Structure and Economic Life of the Circassian settlers in the Ivraca and Rahova Regions of Bulgaria in the 1860s and 70s

\section{Abstract}

Towards the end of the Russo-Caucasian war in the 1860s, Tsarist Russia forcibly deported thousands of Circassians to the Ottoman Empire, some of whom ended up in the Balkans, including the Ivraca (Vratsa) and Rahova (Oryahova) districts of Bulgaria, where 19 Circassian settlements were founded.

The demographic structure of the Circassian families was as such that average family size was 3.3 people, while there were also instances of families of eight. Most families had two children, but a few families had up to five children. There was a significant numerical disparity between boys and girls, as well as men and women for reasons that this article has not been able to identify.

While Rahova was located in the plains and had lands suitable for cultivation, Ivraca was a mountainous district and as such characterized by non-arable lands. Therefore, Circassians mostly engaged in raising livestock were settled in Ivraca, whereas many Circassians in Rahova were employed as day laborers. Circassians encountered no problems regarding the size of their plots. The crop yields depended on such factors as natural disasters, soil quality, and effective management, as well as individual needs and endurance. It is likely that the majority of the Circassian families in the Rahova district were able to provide enough produce for a family of four for a whole year; some even sold the surplus crops in local markets. In summary, Circassians, like other farmers elsewhere, were heavily dependent on the harvest of their crops.

Circassians lived in these districts until the Russo-Ottoman War of 1877-78, during which Circassian settlers were uprooted again and forced to move to the Ottoman lands in Anatolia and the Middle East. Hence the Circassian presence in Bulgaria came to an end.

Keywords: Circassians, deportation, Bulgaria, population, kinship, farming, livestock 


\section{Giriş}

Çerkeslerin 1859-1864 yıllarında Osmanlı İmparatorluğu'na göç ettirilmesinin nedenleri hakkında farklı görüşler ileri sürülmektedir. Bazı bilim adamları, Osmanlı Devleti'nin tutumunun Kafkasya'dan yapılan göçlerde birinci derecede etkili olduğunu belirtmektedir. Kemal Karpat'a göre, Osmanlı Devleti'nin tarım alanlarını işleyecek, ekonomik kalkınmaya katkıda bulunacak gayrimüslim nüfus karşısında dengeyi sağlayacak unsurlara olan intiyacı Kırım Savaşı'ndan sonra daha da artmıştır. Bu ihtiyaç çeşitli bölgelerden göç ettirilen muhacirlerin yerleştirilmesi için elverişli bir ortam oluşturmuştur. Bazı araştırmacılar ise Osmanlıların Kafkas Müslümanlarını kesinlikle yurtlarından atmaya karar veren Rusya Hükümeti'nin baskısı karşısında bu insanları sadece insanî niyetlerle kendi ülkesine kabul ettikleri düşüncesindedir (Karpat, 2002: 653; Karpat, 2002a: 205-206; Muchinov, 2013: 171-172; Saydam, 1997: 77-78.).

Dönemin basın organlarında Çerkesler hakkına önemli bilgi ve haberlere rastlamak mümkündü. İstanbul'daki Bulgar topluluğunun sorunlarını ele alan Tsarigradski Vestnik gazetesi 14 ve 21 Nisan 1856 tarihli sayılarında, Çerkeslerin bağımsızlık isteğini, Rusya'nın tartışıımaz idaresini kabul ettirmesine yönelik çabalarına karşı koymalarını ve vatan uğruna hayatlarını feda etme kararlılığını okuyuculara bildirmekteydi.

Adı geçen Bulgar gazetesi Batı Avrupa devletlerinin Paris'te düzenlenen barış görüşmelerinde Çerkeslere karşı kayıtsızlıklarını vurgulamaktadır. Çerkeslerin sultanın himayesi altına girmelerini konu eden Tsarigradski Vestnik gazetesi bir göç intimalinden bahsetmemektedir (Tsarigradski Vestnik, 1856: 6/271-272). Belki o günlerde kimse Rus-Çerkes savaşının feci sonuçlarını tasavvur edemiyordu. Göç Çerkeslerin bağımsızlık ve onur anlayışına tamamen zıt düşen bir ihtimaldi.

Temmuz 1862-Ağustos 1863 döneminde Tasvir-i Efkâr gazetesi RusÇerkes mücadelelerini anlatmakla birlikte göç ihtimalinden bahsetmemektedir (Tasvir-i Efkâr, 29 Temmuz 1862; Ağustos 1862; 11 Ağustos 1862; 17 Kasım 1862; 19 Ocak 1863; 8 Mayıs 1863; 10 Ağustos 1863). Hatta 10 Ağustos 1863 tarihli nüshasında hiçbir ailenin Çerkesya denilen bölgeyi terk etmeyeceğini vurgulayıp herkesin Rus kuvvetleriyle savaşmaya ve vatanını savunmaya hazır olduğunu ileri sürmektedir. Ancak 14 Aralık 1863 tarihli sayısında, yani Trabzon'a 10.000'den fazla 
ailenin gelmesinden sonra, Tasvir-i Efkâr gazetesi Çerkes göçlerini onur ve özgürlük gerekçeleriyle savunmaktadır. 7 Ocak 1864'te, hiçbir Avrupa devletinden yardım alamayan Çerkeslerin Rus memurlar tarafından direnişten vazgeçmeleri için ikna edilmeye çalışıldığını bildirmektedir. Ama yaklaşan faciaya ve yavaş yavaş artan ümitsizliğe rağmen Tasvir-i Efkâr gazetesi Tuapse bölgesinde bağımsızlığını müdafaa etmeye kararlı birçok Çerkes ailesinin kaldığını vurgulamaktadır. Rusya'nın Kafkasya politikasını kabul etmeyen ve görüşlerini açıkça ifade eden Tasvir-i Efkâr gazetesi Çerkeslerin de Rusya'ya karşı ayaklanan Polonyalılar gibi uluslararası desteğe layık oldukları fikrindedir (Tasvir-i Efkâr, 10 Temmuz 1863; 10 Ağustos 1863; 7 Aralık 1863; 14 Aralık 1863; 7 Ocak 1864). Rus-Çerkes çatışmalarını yansıtan Osmanlıca makaleler, sadece Kafkasya'daki durumu değil, trajik sonu çoktan belli olan bir mücadelenin kahramanlıklarını da anlatmayı amaçlamaktadır. ${ }^{1}$

İster gazete haberlerini tercih eden araştırmacılar, isterse Rusya'nın ya da Osmanlı İmparatorluğu'nun tutumunu ele alan bilim insanları büyük bir trajedinin yaşandığı gerçeğini de vurgulamak zorundadır. Nitekim birçok araştımacı Osmanlı İmparatorluğu'na göç ettirilen Çerkeslere yapılan yardımlar, çekilen zorluklar, ilk aylardaki hastalıklar ve yüksek ölüm oranı hakkında ayrıntılı bilgiler vermektedir (Aydemir, 1988; Bayraktar, 2007: 405-434; Berber, 2011: 17-49; Bice, 1991; Çiçek, 2009: 57-88; Gutheil, 2003: 139-168; Güneş, 2014: 421-452; Kara, 2013: 333-344; Karataş, 2012: 99-138; Keleş, 2009: 1166-1188; Pul, 2011: 181-207; Şaşmaz, 1999: 331-366; Tutum, 1993: 3-41; S. Yel-A. Gündüz, 2008: 949-983). Bulgaristan Milli Kütüphanesi doğubilim (oryantal) bölümünde muhafaza edilen Osmanlı belgeleri, gerek Hıristiyanların ve Müslümanların, gerekse Kafkasya ve Kırım muhacirlerinin gündelik yaşamı hakkında geniş bilgiler sunmaktadır. Bu makalede İvraca ve Rahova kazalarına yerleştirilen ama 6 Ağustos 1878'den sonra Berlin Antlaşması şartlarına ve Kont Dondukov'un emrine (Ovsiyani, 1906: 24; İkonomov, 1885: 231, 233) uyarak Bulgaristan Prensliği'ni terk edip Anadolu, Suriye ve Ürdün'a göç etmeye mecbur kalan Çerkeslerin demografik yapısı ve iktisadi etkinlikleri incelenmeye çalışılacaktır.

\footnotetext{
${ }^{1}$ Gerek Kafkas-Rus Savaşı, gerekse Çerkesler ve Kırım Müslümanları hakkında ayrıntılı bilgiler sunan ve 19. yüzyılda Rusça yayımlanan kitaplara www.vostlit.info sitesinden ulaşılabilir.
} 
1864-1876 yıllarında Tuna vilayetinin İvraca ve Rahova kazalarına bağlı toplam 134 köyde Hıristiyanlar ve Müslümanlar yaşıyordu. Günümüzde bu köylerin yirmi dört tanesi Plevne, Lofça, Montana ve Sofya illerine bağlıdır. Diğerleri de İvraca ilini oluşturmaktadır. Rahova kazası Tuna nehrinin güney sahillerinden Balkan Dağları'nın kuzey eteklerine kadar uzanıyordu. İvraca ve Rahova kazalarının ortak sınırı Suhaçe ve Gabare, Komarevo ve Bırkaçevo, Nivyani ${ }^{2}$ ve Borovan, Tri Kladentsi ve Devene, Gradeşnitsa ve Lesura köyleri arasından geçiyordu. Beli Brodve Mihaylovo ${ }^{3}$, Bızovets ve Kozloduy köylerini de içine alan Rahova kazası doğuda Tuna ovasından geçen İskır nehrinin batı kıyılarına ve Reselets köyüne kadar uzanıyordu. Geniş düzlüklerin ve küçük tepeciklerin birbiriyle bütünleştikleri Rahova kazasında oldukça verimli kara toprakların sadece bir kısmı tarıma açılabilmişti. Dağılı İvraca kazası ise batıda Lehçevo köyünden başlayıp güneybatıda Dobruşa, Pudriya, Beli İzvor köylerini ve İvraca Balkanı́nın güney eteklerini içine alıyordu. Kuzeydoğu doğrultusunda Zlidol, Tipçenitsa, Sinö Bırdo, Belentsi, Oreşets köyleri ve Roman kasabasıyla birlikte Karlukova köyüne kadar uzanıyordu (Salname, 1873: 183, 185, 189, 191, 193; Bulgaristan Haritası 1998; Kanitz, 1880). İki kazanın ovalık ya da dağlık yapısı yerlilerin ve muhacirlerin geçiminde belirleyiciydi.

Bulgaristan Milli Kütüphanesi'ne bağlı Doğu (Oryantal) bölümünde muhafaza edilen Osmanlı belgeleri Vidin sancağına bağlı Adliye (Kula), Berkofça, Belogradçık, Lom kazalarında yaşamış Çerkesler ve Kırım göçmenleri ile yerli halk geniş bilgiler sunmaktadır. Bu makalede, İraca ve Rahova kazalarındaki Çerkeslerin demografik yapısı ve iktisadi etkinlikleri incelenmeye çalışılacaktır. Ortaya konulan sonuçların ve tahminlerin diğer kazalara yerleştirilen muhacirler için de geçerli olup olmadı̆̆ının araştırılmasında önemli bir veri kaynağı oluşturmaktadır ve kapsamlı bir çalışmada yer almaya değerdir.

2 Nivyani olarak bilinen köy Osmanlı belgelerinde Curilova olarak geçmektedir (Miçev, 2005: 257).

3 Mihaylovo köyü Osmanlı belgelerinde Dolna Gnoynitsa olarak geçmektedir (Miçev, 2005: 245). 


\section{Illk Günler, Yardım ve Yerleşim Yerleri}

1873 yılında yayımlanan Tuna Vilayeti salnamesinin Rahova ve İvraca bölümleri Vidin, Berkofça, Belogradçık ve Lom bölümlerinden farklı olarak muhacir köyleri hakkında herhangi bir bilgi vermemektedir (Salname, 1873: 169, 171, 177, 181, 195). Çerkes ailelerinin yerleştirildiği köyler, Rahova ve İvraca muhacir mültezimleri listeleri ve öşür senetleri yardımıyla tespit edilebilmektedir (Bulgaristan Milli Kütüphanesi (BMK, Or. B., F. 29A: 440/29, 843/32, 773).

İvraca kazasına bağlı 9 Çerkes köyü vardır: Bukofçe (Bukovets), Devene, Kamenno Pole, Kunino, Lik, Meciye ${ }^{4}$, Tipçeniçe (Tipçenitsa), Virovsko ve Vırbeşniçe (Vırbeşnitsa). Nisan 1865'ten önce bu köylere yerleştirilen muhacirlerin bir kısmının vefat etmesi üzerine dul eşleri ve yetimleri yalnız kaldılar. Bazıları ise başka kazalarda barındırılan akrabalarının yanına gittiler (BMK, Or. B., Vidin 5/29.).

Rahova kazasına bağlı Çerkes köylerinin sayısı 10'dur: Bregare ${ }^{5}$, Beli Brod, Bırzina, Dıbniçe ${ }^{6}$, Furen, Hayreddin, Maligrad (Malorad), Sovat ${ }^{7}$, Tırnava ve Üçbunar (Tri Kladentsi). Sovat köyünde sadece Çerkesler, Bregare köyünde Çerkesler ve Kırım Müslümanları, başka yerleşim yerlerinde ise Çerkes aileleri yerlilerin yanında oturuyordu. Kasım 1864'ten önce Rahova'nın Çarşu mahallesine yerleştirilen Çerkesler

${ }^{4}$ İzleri kalmayan Meciye köyü Osen, Çiren köyleri ve Krivodol kasabası arasında bulunmaktaydı (Bulgaristan Haritası 1998; Kanitz, 1880).

${ }^{5}$ Elimizde bulunan tek bir belgede Bregare köyü Aziziye olarak çift adla da geçmektedir. Belki, Lofça kazasına bağlı Teliş mezrasında kurulan ve yine Aziziye diye adlandırılan bir Tatar köyünü Rahova kazasındaki Aziziye köyüyle karıştırmamak için yerel Osmanlı makamları Bregare köyünün yeni adını kullanmaktan vazgeçtiler. (BMK, Or. B., 32/773; Saydam, 2010: 166)

${ }^{6}$ Günümüzde Enitsa barajı yakınında bulunan Dıbniçe köyünden iz kalmamıştır. (Bulgaristan Haritası 1998; Kanitz, 1880).

${ }^{7}$ 1877-1878 Rus-Osmanlı savaşından sonra tahrip edilen Sovat köyü ise Nivyani, Komarevo, Sokolare köyleri ve Borovan kasabası arasında merkezi bir yer almaktaydı. Elimizde bulunan tek bir belgede Sovat köyü Muradiye olarak çift adla geçmektedir. Ama Lom kazasına bağlı ve adı yine Muradiye olan bir Tatar köyü vardı. Bregare köyü hakkında ileri sürdüğüm tahminler göz önünde bulundurularak Sovat köyünün de Osmanlı belgelerinde neden eski adıyla geçtiği kolayca anlaşılmaktadır. (BMK, Or. B., 31/337; 32/773; Bulgaristan Haritası 1998; Kanitz, 1880). 
yüksek oranda can kaybı yaşadı. Ancak sonraki yıllarda Rahova'da yaşamaya devam eden birçok Çerkes ailesi mülkleri için tapu belgelerini aldı (BMK, Or. B., 32/965, 1096).

Çerkes muhacirlerini karşılayıp hızlı bir şekilde yerleştirmek üzere Şubat 1863'te Rahova ve İvaca kazalarındaki idari makamlar ön hazırlıklara başladı. Vidin sancağına gönderilecek 6706 Çerkes ailesinden 1600'ünün Rahova kazasında ve diğer 250 ailenin İvraca kazasında barındırılması planlandı. Yerel idarecilere göre her aile ortalama 4 kişiydi. Her muhacire günde 640 gram mısır ve 640 gram buğday verilmek üzere 3 ay yetecek mısır ve buğday tedarik edildi. Ayrıca 350 tırmık ve tırpanın, 1400 çapa ve baltanın, 450 arabanın, 350 öküz ve atın sağlanması öngörüldü. Yerlilerin Rahova kazasında inşa ettikleri evler Mart 1864'ten önce hazırdı (BMK, Or. B., Vidin 1/39; 32/961.), ama Çerkes ailelerinin Rahova ve İvraca kazalarına tam olarak ne zaman geldikleri şimdilik tespit edilememektedir.

Haziran 1864-Mayıs 1865 döneminde birkaç İvracalı ileri gelenin terekelerinde kayıtlı olan bağışlardan küçük yardımların tahsis edildiği anlaşılmaktadır. Şafi Kirman'ın vakfettiği tutardan 100 guruş ayrılarak fakir Çerkeslere verildi. Ayrıca Ramazan ayında (28 Ocak-25 Şubat 1865) medreseye devam eden Çerkes öğrencilere 75 guruşluk ekmek de temin edildi. Mustafa bin Hacı Veysi Muhtar'ın bağışladığı para sayesinde 641 guruşluk basma ve 340 guruşluk Amerikan kumaşı alındı (BMK, Or. B., 29/178). Temmuz 1865'te Çerkeslere 588 entari, 594 gömlek, 44 çift şalvar ve 554 çift potur, 2 tane şami (yemeni), basma, şayak ve Amerikan gibi kumaşlar, 500 çanak çömlek, 350 testi ve ibrik bağışlandı. İvraca müdürü, yerel hekim, İdare Meclisi üyeleri, tapu kâtibi, Müslüman ve Yahudi ileri gelenleri, Hıristiyanlar, köylüler, çömlekçi, kürkçü ve abacı esnafı bu kampanyaya katıldı (Tuna, 4 Ağustos 1865).

İraca ve Rahova kazalarındaki Çerkes köylerindeki mektep binaları, çeşmeler, yol ve köprülerin inşaatı hakkında elimizde veri bulunmamaktadır. Belgeler Meciye, Devene, Lik ve Kunino köylerine sınavla seçilen imamların tayin edildiğini ve bir Çerkesin Mart 1876Şubat 1877 döneminde Hayreddin köyünde müezzinlik görevini yerine getirdiğini göstermektedir (BMK, Or. B., 29/825; 32/990.). Bu nedenle sözü geçen köylerde cami tipinde yapıların bulunduğu düşünülebilir. Nisan 1874'te Üçbunar köyünde çıkan bir yangında 54 ev hasar gördü. 
Yanan evlerin bazıları Çerkeslere aitti. İnşaat masraflarının acilen karşılanması için belli bir meblağ, sonraki aylarda Vidin sancağı muhacir öşründen geri ödenmek üzere bedel-i askeriye gelirlerinden borç alındı (BMK, Or. B., 32/611; İztoçno Vreme, 20 Nisan 1874).

Kasım 1876'da Üçbunar, Sovat ve Tırnava köylerindeki Çerkes evleri yoklanıp sahiplerine tapular verildi (BMK, Or. B., Oryahovo 14/7). Ev sahibinin yanı sıra, yoklama defterine evin maliyeti, komşuların isimleri ve yanında bulunan yapılar kaydedilmiştir. Buna rağmen bir köy haritasının çizilmesi mümkün değildir. Çünkü komşu olarak gösterilen kişilerin bazıları ev sahibi olarak verilmemektedir. Bu şekilde, yoklama defterinde sınırları tam bilinmeyen arsalar da yer almaktadır. Sahip olarak kaydedilmeyen kişilerin tapu almak istemediklerini ya da akrabalar arası ilişkilerden ötürü tapu almaya hakları olmadığını düşünebiliriz. Az sayıda aile 1000 guruşluk ya da daha yüksek maliyette olan evlere sahipti. Evlerin çoğu 500 guruş değerindeydi. Bu maliyetteki ev, Kırım ve Kafkasya muhacirlerinin acil barındırılması amacıyla hızlıca inşa edilen basit bir yapıydı (Tuna, 14 Ağustos 1866; Dorev, P., 1940: 362). Dolayısıyla 1876 yılında birçok Çerkes ailesinin ilk geldiklerinde aldıkları evlerde oturmaya devam ettikleri tahmin edilebilir (Tablo 1 ).

Üçbunar köyünde yaşayan 24 ailenin hepsi 250 guruşa mal edilebilen evlere sahipti. Tüm bu ailelerin Nisan 1874 yangınından önce ilk evlerini yapıp yapmadıkları ya da yangında kaybedip etmedikleri bilinmemektedir. Belki de, 250 guruşluk evlere sahip olan bazı ailelerin daha büyük yapıya intiyacı da yoktu. Aralarından 12'si 1871 öşür defterinde de geçmektedir. Aşağıda ayrıntılı olarak ele alınacak 1871 hasadına göre, biri yoksul, dördü ise satılacak hububat fazlası bulunmayan son derece dar gelirli 5 aile mevcuttu. Hasatlarından geri vermek şartıyla $1875^{\prime}$ te bu 5 aileye yardım yapıldı. Diğer 7 ailenin ikisi dar gelirli, ikisi varlıklıydı. Üçü ise orta sınıfa mensuptu. Onların satabilecekleri bir miktar hububat fazlası bulunmaktaydı (BMK, Or. B., Oryahovo 14/7; 32/857; 32A/98). Nakit vergilerini ödedikten sonra kalan parayı nereye harcadıkları sadece tahmin edilmektedir. Gerek yangından ötürü, gerekse 1875'te geri vermek şartıyla borç olarak aldıkları hububattan ya da tamamlayamadıkları ev ihtiyaçlarından dolayı bu 12 aile 1876 'da da basitçe inşa edilmiş evlerinde oturmaya devam ediyordu. 
Tırnava köyünde ise 250-750 guruşluk evlerin sayısı 1000 guruşluk ya da daha yüksek maliyette olan evlerin sayısına neredeyse eşittir. Tırnava'daki Çerkes ailelerinin aldıkları topraklarla ilgili verilerin dışında buradaki Çerkes topluluğu hakkında elimizde başka bilgi yoktur. 1860'larda ve 1870'lerde Dobrolevo, Altimir, Galiçe, Bırdar Bunar (Bırdarskigeran) köyleri ile Byala Slatina kasabasından 6.5-7 km uzaklıkta bulunan Tırnava köyünde yaşayan yerlilerin ve muhacirlerin yeni tarlalar açma imkanları vardı. ${ }^{8}$ Tırnava köyü yakınından Skıt ve Greznitsa akarsuları geçmektedir, toprak da son derece verimlidir. $\mathrm{Bu}$ elverişli doğal etkenler Çerkeslerin tarımsal faaliyetlerini olumlu yönde etkilemiş ve bazıları kazandıkları paralarla evlerini yenilemiş olabilirler.

\section{Demografik Özellikler}

Çerkes topluluğu tehcir günlerinde yüksek derecede can kayıpları yaşadı. Gemi ücretlerini ödemek için fakir Çerkes aileleri kız çocuklarını feda etmeye mecbur kaldı. Bu çocukları alan köle tüccarları onları Osmanlı İmparatorluğu'nda satmaktaydı. Köle ticaretini sınırlayıp yok etmeye çalışan Babıali, Haziran 1864'te taşra makamlarına köle olarak satılan kızların araştırılarak bir an önce akrabalarının yanına yerleştirilmelerini emretti (BMK, Or. B., 26/11541; Toledano, 1994: 35-41, 49-50, 76, 85, 96-105, 117-119, 125-159).

İvraca kazasındaki Çerkes nüfusuna ışık tutan defterler elimizde bulunmamaktadır. 1867'de hazırlanan 3 emlak defterine göre Bukovets köyünde 40, Kamennopole köyünde 26, Meciye köyünde 68 aile yaşamaktaydı (BMK, Or. B., 29/605-606; 29A/275).

Mayıs 1877'de Çerkeslerin ve Kırım Müslümanlarının askeri birliklere katılmaları gerektiğinde, Rahova makamları kazada silah altına alınacak 1800 Çerkes bulunduğunu sancak merkezine bildirmişti (BMK, Or. B., Oryahovo, 16/14: 10). Hayreddin köyüne yerleştirilen Çerkes ailelerin hane halkı ve yapısı hakkında 15-27 Ekim 1873 tarihli nüfus defterinden bilgiler edinmekteyiz. Verilerin eksik olduğu Dıbniçe köyü dışında, Rahova kazasına bağlı diğer Çerkes köylerinde hane

${ }^{8}$ Ayrı ayrı köyler arasındaki mesafelerin tespitinde Google Maps imkânlarından da faydalandım (Bulgaristan Haritası 1998; Kanitz, 1880). 
birimlerinin tespit edilmesi için emlak, öşür, iane ya da yoklama defterleri değerlendirilmiştir (Tablo 2).

1867, 1871 ve 1876 verilerine göre Sovat ve Tırnava köylerinde oturan Çerkes ailelerin sayısı hemen hemen hiç değişmedi. 1867-1871 döneminde Üçbunar ve Furen köylerinde Çerkes ailelerin sayısı \% 28 ve $\% 19$ oranlarında azaldı.

Yerel Osmanlı makamlarının Sovat, Üçbunar ve Tırnava köylerinde toprak dağıttıkları aile reislerinin kayıtlı olduğu 1867 yılına ait defterler incelendiğinde birçok arazi sahibinin adının başka defterlerde de geçtiği görülmektedir. Sovat köyünde toprak sahibi olan 300 ailenin 67 'si 1876 'da kendi evlerinde yaşıyordu. Sovat köyü emlak defteri yer yer yırtılmış olduğundan 65 aile reisinin isimleri tespit edilememiştir. Bazılarının 1871 ve 1876 defterlerinde de yer alıyor olması muhtemeldir. Fakat şimdilik 1867-1876 yıllarında Çerkes ailelerinden en az yüzde 22'sinin Sovat köyünde kaldıkları kabul edilmektedir (Tablo 3).

Üçbunar civarında toprak alan 41 aile 1876 yılında da aynı köyde yaşamaktadır. 1867 emlak defteri ve 1875 iane defteri karşılaştırıldığında, 1867 yılında toprak sahibi olan 44 Çerkes ailenin 1875 yılında da Üçbunar köyünde yaşadıkları tahmin edilmektedir (Tablo 4). 1867'de Tırnava köyünde toprak alan 35 Çerkes ailesi 1876 yılında aynı köyde yaşamaya devam etmekteydi (Tablo 5).

Daha önce belirtildiği gibi, 1876 yoklama defterinde komşu olarak gösterilen bazı Çerkesler ev sahibi olarak ve tam adlarıyla kaydedilmemiştir. Bazılarının tapuları yoksa da, toprak sahibi oldukları varsayılabilir. Tespit edilen bu eksiklikleri göz önünde bulundurarak, 1867-1876 yıllarında toprak sahibi olan Çerkes aileden \% 43-44'ünün söz konusu köylerde oturmaya devam ettikleri düşünülmektedir. Incelenen defterlerde adı sadece bir defa geçen ailelere de rastlanmaktadır. Bu ailelerin 1876 yılına kadarki yaşamları hakkında sadece tahminler yapılabilir. Bazı toprak sahiplerinin çocukları ya da yakın akrabalarının 1867'den birkaç yıl sonra babalarııın ve amcalarının yerlerine geçmiş olmaları ihtimal dahilindedir. Bir kısım ailenin geçim zorluğu nedeniyle akraba, komşu ya da yakın ailelerin himayesi altına girip yanlarına taşınmış olduğu düşünülebilir. Boş evlere ise başka Çerkes ailelerin yerleştirilmiş ve arazi verilmiş olması mümkündür. 
1875 iane defterleri araştırılarak Üçbunar, Beli Brod, Maligrad ve Tırnava köylerinde yaşayan Çerkes ailelerinin hane halkı hakkında bazı tespitler yapılabilir. Şiddetli kış nedeniyle Rahova kazasındaki Hıristiyanlara ve Müslümanlara ${ }^{9}$ arpa ve koçanlı mısır $^{10}$ yardımı yapılmıştır. Yardımın süresi ve kişi başına düşen günlük miktar defterlerde belirtilmemiştir. Çerkeslerin ayrı ayrı köylere yerleştirildikleri günlere benzer şekilde, yine 640 gramlık günlük yardım yapılmış olması muhtemeldir. Hububat ise 30, 60 ya da 90 günlük süreler için öngörülmüş olmalıdır.

Hesaplamalarımıza göre, alınan mısır miktarının çoğu 60 günlük süre içinde tüketilirse, hane halkı 8 kişiye kadar olan bir ailenin gıda ihtiyacını karşılamaktadır. Ayrıntılı olarak anlatılacak Hayreddin köyündeki Çerkes aileleri en fazla 8 kişiden oluşmaktadır. Dolayısıyla söz konusu tahılın 60 gün yetecek şekilde planlanmış olduğu düşünülebilir (Tablo 6).

Tahminlere göre, yardım alan üç, altı ya da yedi-sekiz kişilik ailelerin sayısı 9 ila 12 arasında değişmektedir. Ailelerin çoğu iki ya da beş kişiliktir. Üçbunar köyünde yaşayan iki kişilik ailelerden 11'i 1871 yılında en az 9 kişiye yetecek mısır elde ettiklerinden, bu tarihlerde söz konusu ailelerin 2 kişiden ibaret olmaları mümkün değildir. Ancak sınırlı hububat yardımında birçok olumsuz etken rol oynamaktadır. Nisan 1873 tarihindeki yangında bu 11 ailenin varlıklarını kaybetmiş ve üyelerinin dağılmış olması muhtemeldir. Daha iyimser bir intimal de vardır. Bu 11 aile 1875 'in kış aylarında gerekli tahıın bir kısmını satın alıp bir miktar da yardım alarak iaşelerinde büyük zorluk çekmemişlerdir. Bu varsayıma göre, 1875'te Üçbunar köyündeki iki kişilik ailelerin sayısı daha düşük olmalıdır.

${ }^{9}$ Çerkeslere sağlanan ianenin dışında Krıva Bara ve Kozloduy köylerindeki Kırım Müslümanlarına, Bara ve Palanka mahallelerinde, Tırnava, Rogozine, Stavrevtsi, Ostrov, Bukovets, Saray, Kruşoviçe, Altimir, Lesoran, Borovan, Bırzine, Hırlets, Leskovets, Beli Brod köylerinde ve Rahova'nın Cami-i Kebir ve Yanık mahallelerindeki yerli halka önemli miktarlarda hububat da temin edilmiştir (Vek, 8 Mart 1875; BMK, Or. B., Oryahovo, 16/2; 32/26, 798, 856857, 1008; 32A/171, 284, 291, 444-451, 616, 799-800, 850, 1018.

${ }^{10}$ Koçanların tedarik edilen mısır miktarının yüzde 20 'sini oluşturduğu kabul edilmiştir (Mitkov, 1961: 38, 43). 
15-27 Ekim 1873 tarihli nüfus defteri (BMK, Or. B., Oryahovo, 16/3) Hayreddin köyünde yaşayan Çerkes ailelerin kişi sayısına ve yapısına ışık tutmaktadır. Toplam 179 aileden ya da 579 kişiden oluşan bu Çerkes topluluğunda 91 kız, 125 erkek çocuk bulunmaktadır. Bu durumda 100 kız çocuğuna 134 erkek çocuğu düşmektedir. Kadınlar 177, erkekler ise 204 kişidir. Böylece 100 kadına 114 erkek düşmektedir. Fakat dünyaya yeni gelen kız ve erkek çocukları arasındaki oran 100/105 ya da 100/106 şeklindedir (Cox, 1976: 182; Todorova, 2006: 21.). Buna göre, Hayreddin köyünde cinsiyetler arasında önemli bir dengesizliğin olduğunu belirtmek gerekir. Ekim 1873'te kadın erkek dengesi 100/124 oranındaydı. Babadağ kazasındaki Çerkes topluluğunu araştıran $\mathrm{M}$. Todorova da buna yakın bir oran tespit etmektedir (Todorova, 2006: 22).

Söz konusu nüfus defterinde Çerkeslerin yaşları belirtilmemiştir. Bu eksiklik bir yandan ayrı ayrı ailelerin iş gücü ve girişimcilik potansiyeli hakkında belli tahminlerin yapılmasını engellerken diğer yandan da, ayrı ayrı yaş gruplarında cinsiyetler arasındaki dengenin hesaplanması, kadınların hangi grupta önemli ölçüde azalmaya başladıklarının ve nedenlerinin araştırıması imkânını da ortadan kaldırmaktadır. Kız çocukları köy dışından evlendiriliyor ya da başka yerleşim yerlerinde hizmetçi olarak çalıştırılıyordu. Sağlık koşulları nedeniyle ölüm oranının yüksek olma ihtimali de göz önünde bulundurulmalıdır. Muhtemelen erkek çocuklarının çoğu iş gücü olarak aile içinde kalmaktadır.

Hayreddin köyündeki bir Çerkes ailesi ortalama 3.3 kişidir. Iki ve dört kişilik ailelerin sayısı hemen hemen birbirine eşittir. Üç kişilik ailelerin sayısı önemli bir düzeydeyken, 6-7 kişilik ailelerin sayısı sınırıdır (Tablo 7). Ekim 1873 'te Hayreddin köyünde yaşayan Çerkes ailelerinin yapısı incelendiğinde çoğunun bir ya da iki çocuğa sahip olduğu tespit edilmektedir. Toplam 17 ailenin üçer çocuğu vardır. Dört ya da beş çocuklu aileler hemen hemen istisnadır. Çocuklu dul kadınların oranı \% 7, çocuksuz hanelerin oranı ise \% 13'tür (Tablo 8). Dul kadınların geçimlerini nasıl sağladıkları sorusuna şimdilik net bir yanıt verilememektedir. Bazıları Kunino, Meciye, Tipçeniçe, Bukofçe, Vırbeşniçe, Virovsko ve Devene köylerinde yaşayan dul Çerkes kadınları gibi (BMK, Or. B., İvraca 18/7; 18/8) yerel Osmanlı makamlarının ianesiyle geçiniyor olabilir. Yalnız yaşayan erkekler arasında, evli çocukları tarafından bakılan yaşılırın olup olmadığı tespit 
edilememektedir. Herhalde, çoğu önemli problemler yaşamadan geçimini sağlamaktadır.

Toplam 6 Çerkes erkeğinin ikişer eşi vardır. Bu ailelerden biri 5 kişilik, ikisi 6 kişilik ve üçü 8 kişiliktir. Çocukların sayısı ise 2 ile 5 arasındadır. Hayreddin köyündeki Çerkeslerin tarımsal etkinliklerine ya da zanaatlarına ışık tutan veriler elimizde bulunmadığından iki eşi olan erkeklerin sosyal statüsü de belirsiz kalmaktadır. Muhtemelen aralarında dar gelirli aile reisleri de yer almaktadır. Topluluğun dayanışma geleneklerine uygun olarak dul bir kadını ya da fakir bir kızı ikinci eş olarak alıp geçimlerini temin etmiş olabilirler.

Hayreddin köyündeki aile reislerinin isimleri karşılaştırılarak aileler arasındaki akrabalık bağlantıları hakkında bazı tahminler yapmak mümkündür. Baba adlarına göre aile reisleri 33 gruba ayrılmaktadır. Ayrı grupların sayısı 2 ile 5 aile arasında değişmektedir. Oluşturulan akrabalık modelleri gerçekse (Tablo 9), Hayreddin köyünde yaşayan Çerkes ailelerine özgü şu özellikler ön plana çıkmaktadır. Evli olmayan kardeşler geçimlerini tek başına sağlıyorsa ayrı bir hane oluşturmaktadır. Geçimlerini sağlayamayan bekâr erkek kardeşler ağabeylerinin yanında, yani aile çevresinde kalmaktadır. İlk eşler ya da dul anneler oğullarından birinin yanında yaşamaktadır. Çerkeslerin bir köye yerleşmesi de akrabalık ilişkileriyle bağlantılıdır. Böylece yaşlı anne babalar olarak kabul ettiğimiz çiftler geçimlerini tek başına sağlamak zorunda kalmayıp, oğullarından destek almaktadır. Bu özellikler Çerkeslerin Balkanlar'daki yeni koşullara çabuk uyum sağlamasında etkili olmuştur. Hayreddin köyünde, akrabalık bağlarını koruyarak dayanışma için uygun koşulları yaratan Çerkes topluluğu, aşırı yoksulluk ihtimalini önemli ölçüde azaltmıştır. Bunun yanında yoksul aileler devletten de yardım almıştır.

\section{3. İktisadi Etkinlikler}

\subsection{Genel Bilgiler ve Toprak Büyüklüğü}

Rahova ve İvraca kazalarındaki Çerkesler genellikle tarımla geçiniyordu. 1873 yılında Rahova kazasına bağlı tüm Çerkes köylerinde buğday, arpa, darı ve mısır, 1875 yılında Bukovets, Meciye, Devene ve Kunino gibi Çerkes köylerinde ise buğday, arpa ve darı yetiştiriliyordu (BMK, Or. B., Oryahovo 13/15; 29A/202.). 1876 yılında Bukovets köyünde yaşayan birkaç Çerkes ise tütün üretiyordu. Kunino ve Lik 
köylerinde yaşayan toplam 32 Çerkes ailesi 89 koyun ve 119 keçi besliyordu (BMK, Or. B., Ivraca 18/4; 29/105, 498).

1867 emlak defterlerine göre (BMK, Or. B.,Oryahovo 16/2; 32/24, 470, 473-474, 476; 32A/176.) Bregare köyüne yerleştirilen Çerkes ailelerinin çoğu 50 ya da 100 dönümlük ${ }^{11}$ tarlalar aldılar. Başka 6 aileye de 150 ya da 200 dönümlük araziler verildi. Fakat Rahova kazasına bağlı diğer Çerkes köylerinde 60 dönümlük toprak alabilenler sınırlıydı. 90 dönümlük tarlalar ise hemen hemen istisnaydı (Tablo 10a). Bregare'deki arazilerin geniş olması basit bir nedene bağ/ı olabilir: İskır Nehri'nin batı kıyılarına yakın Stavrevtsi ve Kruşovene köyleri arasında bulunan Bregare köyü topraklarını kuzeybatı yönünde Ostrov-İsmail Bunar (Kneja) hattına kadar genişletebilirdi (Bulgaristan Haritası, 1998; Kanitz, 1880). Sovat, Üçbunar, Bırzina, Furen gibi köylerin yakınında kalabalık yerleşim yerleri bulunduğundan ve toprakların önemli bir kısmı yerliler tarafından kullanıldığından 60, 90 ya da 120 dönümlük tarlaların sayısı azdır.

Tespit edilemeyen bir nedenle Sovat köyünde yaşayan 18 Çerkes ailesinin emlakı 1867 defterinde gösterilmemiştir. 9 ailenin kaydı 1871 ve 1876 defterlerinde de yoktur (BMK, Or. B., Oryahovo 14/7; 32/15). $\mathrm{Bu} 9$ ailenin üyelerinin yaşlı olması nedeniyle tarımla uğraşamadıklarını ya da 1867 'den sonra vefat ettiklerini tahmin edebiliriz. Öte yandan bu 9 ailenin 1876 yılında da Sovat köyünde yaşıyor olması intimali vardır; başka bir ailenin ya da akrabalarının himayesi altına girmiş ve defterde ayrı hane olarak gösterilmemiş olabilirler. 1871 yılında yetiştirdikleri mısır miktarları göz önüne alındığında, 9 ailenin 1867'ten sonra toprak sahibi olduğu ya da toprak kiraladığı anlaşılmaktadır. 1876 yılında bu 9 aile oturdukları evlerin tapularını da aldılar.

Yüzyıllarca uygulanmış olan vergilendirme usulüne göre, iki öküz tarafından sürülebilen tarım alanlarının ölçüsünü belirtmek için "çift" ya da "çiftlik" terimleri kullanılmaktaydı. Bir çiftçi ailesine yetecek genişlikte olan çift ya da çiftlik, toprağın verimine göre 60 ile 150 dönüm arasında değişiyordu (Emecen, 1993: 309-310). Muhtemelen 1860'larda Osmanlı makamları 60-150 dönümlük tarlalara sahip her Çerkes ailesinde en az bir çift öküzün bulunması geleneğine uyarak,

\footnotetext{
${ }^{11}$ Bir dönüm 918,393 metrekaredir.
} 
toprak dağıtımında 60 dönümlük ya da daha büyük tarlalar alan Çerkes ailelerine birer ya da ikişer çift öküz ve bazen inek de temin etmiştir. 30 dönüm toprağı olan Çerkes aileleri istisna olarak bir çift öküz alıyordu. Bu nedenle arazilerin bir kısmını bahçe ya da çayırlık olarak bırakmaları ve kalanını, çoğu zaman kazma ve çapayla işlemeleri gerekiyordu.

İvraca kazasına bağlı Kamennopole, Meciye ve Bukovets köylerindeki Çerkes aileleri az miktarda toprak aldılar (Tablo 10b). En büyük araziler 30-36 dönümdü. Meciye köyündeki tüm aileler 21 dönümlük arazilere sahipti. Hiçbir aile çift öküz ya da inek sahibi değildi (BMK, Or. B., 29/605-606; 29A/275). İvraca kazası dağlık ve toprakları taşlık, nüfusça kalabalık bir bölgeydi. Osmanlı makamlarına göre sürülmemiş araziler tarıma elverişli de değildi (BMK, Or. B., 26/11541). Görünen o ki, İvraca kazasına daha çok hayvancılıkla geçinen Çerkes aileleri yerleştirildi ya da birçok Çerkes ovalık Rahova kazasındaki tarlalarda gündelikçi olarak çalışıyordu.

Çerkes aileleri tarlalarını alır almaz topraklarını ekmeye başladı. Emlak defterinin tarihine göre, Rahova kazasındaki Çerkes aileleri topraklarını 1867'de almış olmalıdır. Illk hasatları ise 1868 yılına rastlıyor. 3 yıllık vergi muafiyeti kuralına göre, (Tuna, 16 Mart 1866) ilk öşür vergisini 1870 yılında ödemeleri gerekiyordu. Ancak elimizdeki belgeler öşür paylarının daha 1868 yılında belirlenmiş olduğunu göstermektedir. 1869 yılında ise köy payları iltizama verildi. Bu nedenle Çerkeslerin topraklarını 1865 yılında aldıkları tahmin edilebilir. Arazilerin sahipleri, sınırları ve büyüklüğü emlak defterine daha 1867 yılında ayrıntılı olarak kaydedilmişti (BMK, Or. B., 29A/276, $440 ; 32 / 773)$.

\subsection{Hububat Yetiştirilmesi}

Sovat, Üçbunar ve Furen köylerine ait 1871 öşür defterleri her bir Çerkes ailesinin hasat ettiği zahire miktarı hakkında bilgiler vermektedir. Berkofça, Lom ve Belogradçık kazalarındaki Çerkes ailelerinden farklı olarak (Dobreva, 2013: 19; Dobreva, 2015: 106130.) Rahova kazasındakiler sadece misır hasadına bel bağlamamışlardı. Üçbunar köyünde oturan birçok aile yıl boyunca sırf mısırla yetinmek zorunda olmayıp, günlük iaşelerini mayasız arpa 
ekmeğiyle ${ }^{12}$ ya da buğday ekmeğiyle zenginleştirebiliyordu. Fakat Sovat köyünde yetiştirilen hububatla ilgili veriler sadece mısır miktarına ışık tuttuğundan, söz konusu 3 köyde 1871'de alınan mısır mahsulünü temel gıda olarak kabul etmek gerekmektedir.

Tehcir yıllarında Osmanlı makamları hazırladıkları gıda miktarlarını 4 kişilik aileler üzerinden hesaplıyordu. 1873'te Hayreddin köyünde bir ailede ortalama üye sayısı 3.3 iken, 8 kişilik Çerkes aileleri de vardı. Bu nedenle hasat edilen hububat miktarının bir yıl içinde 4 kişiye yetip yetmeyeceği sorusunu yanıtladıktan sonra, 8 kişilik kaç ailenin bir yıllık gıda ihtiyacını karşılayabildiği ve kaç ailede satılacak hububatın kaldığı sorularına cevap aranmıştır.

1871 yılında Furen köyünde 29 Çerkes ailesi yaşıyordu. 1871 öşür defteri yer yer okunmaz olduğundan, 4 ailenin aldığı hububat miktarına ışık tutan veriler eksiktir (BMK, Or. B., 32A/381). Özetlenen verilere göre, koçanlardan ayıklanmış mısırla, üye sayısı 4-5 kişi olan toplam 7 aile bir yıllık gıda intiyacını karşılayabiliyordu. 18 ailede 1 ila 3 kişiye yetecek kadar mısır bulunuyordu. ${ }^{13} 1871$ yılında Çerkes aileleri buğday ve arpa da yetiştiriyordu. Ailelerin tümünün 8 kişilik bir hanenin hububat ihtiyacını karşılamak için ${ }^{14}$ hasat ettikleri buğday ve

12 Gluteni çok düşük olan arpa genellikle mayasız ekmek için kullanılmaktadır (Winch, 2007: 109).

${ }^{13}$ Açlık çekmemek için bir kişinin bir yıl içinde 245 kilo mısır tüketmesi gerekir. Hasat edilen mısırın bir yıl içinde kaç kişiye yeteceği sorusunun yanıtlanması için iki yöntem uygulanabilir. Tahminlerime göre köylüler öşür vergisini ödedikten ve tohum için bir miktar ayırdıktan sonra hasat ettikleri mısırın \% 66.6'sını tüketebilirdi. Osmanlı makamları ise toplanan mısırın \% $45^{\prime}$ ini rutubetli olduğu gerekçesiyle ve \% 10'unu da öşür vergisi olarak toplam hasılattan düşmekteydi. Böylece, köylülerin tüketecekleri mısır tüm hasılatın \% 45'ini oluşturmaktaydı. Bu makalede Osmanlıların uyguladıkları yöntem kullanılmıştır (Dobreva, 2013: 26; BMK, Or. B., 27/695).

${ }^{14}$ Yıl boyunca açlık çekmemek için kişi başı buğday tüketiminin 273 kilo, arpa tüketiminin ise 292 kilo olması gerekliydi. Sözü edilen 1871 öşür defterine göre Furen köyünde bir buğday demetinden ortalama olarak 2.8 kilo, bir arpa demetinden ise 1.6 kilo zahire alınmaktaydı. Her bir Çerkes ailesinin alacağı ortalama buğday ve arpa miktarlarını tespit etmek için ilk önce biçtikleri buğday ve arpa demetlerinden öşür payı çıkarıldı. Kalan buğday demetleri 2.8 ile arpa demetleri 1.6 ile çarpıldı. Ayrı ayrı miktarların \% 10 'unun tohum olarak ayrıldığı varsayıldı. Kalanı, yıllık buğday ya da arpa 
arpanın tamamını ya da bir kısmını saklamaları gerekiyordu. Toplam 8 aile, ürettikleri buğday, arpa ve mısır miktarı itibariyle 4 kişilik bir ailenin bir yıllık gıda ihtiyacını karşılayamıyordu. Diğer 2 ailede 4 kişilik aileye yetecek hububat bulunuyordu. Bu 10 aile yoksul sayılmaktadır. Üye sayısı tespit edilemeyen 8 aile, 6-8 kişilik bir ailenin bir yıllık hububat intiyacını karşılıyordu. Bu aileler 4-5 kişiden ibaret olursa, sınırlı miktarda hububat fazlasını pazara sunabilirlerdi. Bu 8 aile son derece dar gelirli kabul edilmektedir. Sadece 7 aile hububat fazlasına sahipti ve yine 3 aile 9-12 kişiye yetecek buğday, arpa ya da mısır miktarından bir kısmını satarak belli bir gelir elde edebilirdi. İki aile 1316 kişiye, bir aile 17-20 kişiye ve başka bir aile $21^{\prime}$ den fazla kişiye yetecek kadar tahıl hasat etmişti. Bu 7 aile sırasıyla dar gelirli, orta sınıf, varlıklı ve zengin sayılmaktadır (Tablo 11). 1871 öşür defterinde eksik olan 4 aile bu kesimlerden herhangi birine dahil edildiği takdirde de, 4 ya da 8 kişilik bir ailenin bir yıllık gıda ihtiyacını karşılayabilen aileler Furen köyündeki Çerkeslerin üçte birini oluşturuyordu.

Tek bir aile dışında Furen köyündeki Çerkesler 1871 yılında darı yetiştiriyordu. 4 kişiye yetmeyecek kadar az hububat elde eden aileler için bu darı miktarı günlük iaşelerinin vazgeçilmez bir unsuruydu. Tavuk beslemeyen aileler darıyı satıp 48 ile 235 guruş arasında ek gelir sağlayabilirdi. ${ }^{15}$ Darı miktarıyla birlikte dar gelirli, orta sınıf, varlıklı ve zengin aileler bir miktar buğday, arpa ya da mısırı pazara götürebilirlerdi. ${ }^{16}$ Ancak bu 7 ailenin, yetmeyen mısır miktarını buğdayla tamamlayıp kalanını sattığı tahmin edilmektedir. Satılan buğdayın fazlası 2675 kiloyu, arpanın fazlası ise 1860 kiloyu geçmediğinden ek gelir de 116 ile 1925 guruş arasında değişiyordu.

tüketimiyle karşılaştırarak kaç kişiye yetecekleri tespit edildi. (Dobreva, 2013: 25)

${ }^{15} 1871$ öşür defterinde okka ölçeğiyle verilen darı hacimlerinden $\% 10$ 'u vergi olarak ve kalan miktarlardan $\% 10$ 'u tohum olarak çıkarılmaktadır. 1870'lerde 1 kile darı (25.65 kilo) 6 ile 12 guruş arasında değişen bir fiyatta satılmaktaydı. Çerkes ailelerinin darı miktarlarını 6 şar guruşa sattıklarını kabul etmekteyim. (Andreev, 1993: 433, 592).

${ }^{16} 1871$ 'in son baharında ve 1872 'nin kış aylarında 1 kilo buğday ortalama olarak 19 pareydi, arpanın kilosu 11 pareye ve mısırın kilosu 12 pareye satılmaktaydı (BMK, Or. B., 26/217-219; 181/487; Tuna, 28 Kasım 1871-20 Şubat 1872). 
1871 yılında Üçbunar köyünde 64 Çerkes ailesi yaşıyordu. Mısır, buğday ve arpa miktarları yüzeysel olarak incelenmiş olsa da, 47 ailenin bol miktarda mısır, buğday ve arpa ${ }^{17}$ hasadı yaptıkları, satılacak ya da yardım olarak verilecek tahıl miktarını da ayırabildikleri düşünülebilir. Verilere göre, köyde ne mısır, ne buğday ne de arpa yetiştiren tek bir aile vardı. Bir aile de bir kişiye bile yetmeyecek kadar az tahıl elde etmişti (Tablo 12). Dolayısıyla iki aile de yoksul sayılmaktadır. Mısır, buğday ve arpa miktarlarına göre 5 aile yoksul, 10 aile son derece dar gelirli grubuna girmektedir. Yoksul ve son derece dar gelirli gruplara ait 11 aile kenevir yetiştirerek çuval, halat ve çeşitli ipler imal ediyor ya da işlenmemiş keneviri satarak gelir elde ediyordu. Ürettikleri mısırla 5-8 kişinin bir yıllık gıda ihtiyacını karşılayabilecek 6 aile, elde ettikleri buğday ve arpa miktarı sayesinde 9-12 kişinin geçimini sağlıyordu. Mısııın 9-10 kişiye yetebileceği iki aile, az miktarda buğday ve arpa hasat ettiğinden 3 hububatın toplamı 12 kişinin gıda intiyacına yetiyordu. Bu 8 aile dar gelirliler grubunda yer almaktadır.

5-7 kişiye yetecek mısır üreten dar gelirli ailelerin 4'ü, bir yıl içinde 8 kişilik bir aileye gerekli mısır miktarını buğday ya da arpa ile tamamlayarak fazlasını satabilirdi. Başka 5 aile 8 kişiye yetecek mısır miktarına sahip olduğundan, ürettikleri buğday ve arpa miktarının öşrünü ödeyip tohumluk hububatı ayırdıktan sonra kalanın tamamını satabilirdi. Satılan buğday ve arpadan 158 ila 1415 guruş arasında değişen oranda bir para elde edilmiştir. Bu 9 aileden birkaçı ayrıca darı ve kenevir yetiştirip ek gelir elde ediyordu.

Diğer 38 ailenin her birinde 1960 kilodan fazla mısır ${ }^{18}$ bulunduğundan, buğday, arpa ve darıyla birlikte mısır fazlasını da satabilirlerdi. Aralarında 15 aile kenevir de yetiştirmekteydi. Toplam 27 aile sözü geçen hububatı pazara götürdüğünde 543 ile 1499 guruş arasında değişen meblağlar elde edebilirdi. Bu aileler arasında 12 orta

${ }^{17}$ Üçbunar öşür defterinde hasat edilen saf mısır küfe ve kile ölçekleriyle verilmektedir. Bu verileri göz önünde bulundurarak bir küfenin 59 kilo saf mısır ağırlığında olduğunu hesaplamaktayım. Üçbunar köyünde bir buğday demetinden ortalama olarak 1.4 kilo zahire, bir arpa demetinden ise 2.29 kilo zahire alınmaktaydı. (BMK, Or. B., 32A/98).

${ }^{18}$ Bir kişi yılda en az 245 kilo mısır tüketmekteyse, 8 kişilik bir ailenin 1960 kilo mısıra gereksinimi vardı. 
sınıf, 2 dar gelirli, 10 varlıklı ve 3 zengin aile yer almaktadır. Bu geniş çaplı ek gelirler, birçok ailenin ayrı ekonomik kesimlere mensubiyetine rağmen aktüel iş güçlerine, isteklerine ya da ihtiyaçlarına göre farklı yıllarda çeşitli miktarlarda hububat fazlası elde edebildiklerini göstermektedir.

Birkaç aile hububat satışından 1544 ile 3613 guruş arasında değişen meblağlar elde etmiştir. 11 aile bu zengin ve çok zengin grubuna girmektedir. Fakat kırsal topluluklarda zenginlik kavramı son derece görecelidir. Söz konusu ek gelirler, rüşdiyelerdeki yardımcı öğretmenlerin 1871 yılında aldıkları 3780 ile 3996 guruş arasında değişen maaşlarını aşmamaktadır (BMK, Or. B., Vidin 51/109: 1-2; 26/11136.).

Ayrıca, tarım birçok işlemin kısa süre içinde art arda yerine getirilmesine ve çok sayıda çalışanın birlikte hareket etmesine bağlı bir etkinliktir. Başkalarını çalıştıran bir toprak sahibi, onlara gerek aynî, gerekse nakdî bir ödeme yapmak zorundayd.. ${ }^{19}$ Bu nedenle zengin ve çok zengin olarak kabul edilen aileler sadece Çerkes topluluğu içinde bu özelliğe sahiptir. Orta sınıf, varlıklı ya da zengin gibi gruplara ait olan Üçbunar Çerkeslerinin 1875 kış aylarında aldıkları hububat yardımı, zenginliğin köylüler arasında son derece göreceli olduğunu bir kez daha kanıtlamaktadır. Dağıtılan tahıl miktarlarına göre Üçbunar köyündeki Çerkes aileleri 4 gruba ayrılmaktadır: sadece arpa alan aileler, 12 kiloya kadar hububat alan aileler; 60 gün içinde 2-3 kişiye yetecek 108-186 kilo hububat alan aileler; 60 gün içinde 4-5 kişiye yetecek 192-281 kilo hububat alan aileler. Aralarında $1871^{\prime}$ de hububat üretimine göre ayrı ayrı gruplarda yer alan 25 aile de bulunmaktadır (BMK, Or. B., 32/857; 32A/98). Ailelerin 16 'sı orta sınıfa mensup olan, dar gelirli, varlıklı, zengin ve çok zengin ailelerdir. Diğer 9 'u yoksul ve son derece dar gelirli ailelerdir.

Sovat köyünde yaşayan Çerkesler 1871 yılında bol mısır yetiştirmişlerdi (BMK, Or. B., 32/15). Fakat buğday, arpa ve darı gibi mahsulleri üretip üretmedikleri şimdilik tespit edilememektedir. Hasat ettikleri mısır miktarına göre, Sovat köyündeki yoksul ve son derece dar gelirli aileler, topluluğun üçte birini oluşturmaktadır. Bu ailelerin

${ }^{19}$ E. R. Toledano'ya göre Çerkes göçmenleri arasında tarım köleliği mevcuttu. Şimdilik söz konusu iki kazada böyle olaylar tespit edilememiştir (Toledano, 1994: 126). 
bir kısmı buğday ve arpa yetiştirmelerine rağmen dar gelirli grubuna girebiliyorlardı. Diğer 192 aile, 8 kişiye yetecek mısır hasat etmelerinin yanı sıra yerel pazarlara önemli miktarda mısır sunabiliyorlardı (Tablo 13). Bu hububat fazlasının değeri 91 ila 2433 guruş arasında değişmekteydi.

Arazi büyüklüğü Çerkeslerin tarımsal etkinliklerini hangi yönden etkilemektedir? 1867 emlak defterine göre Furen köyünde 30 dönümlük tarlalara sahip olan 10 Çerkes ailesi 1871 yılında yoksul, son derece dar gelirli kesimlere mensuptur. 60 dönümlük toprak alan 7 aile (BMK, Or. B., 32/474; 32A/381) de 1871'de aynı kesimin içinde yer almaktadır. Aralarından 4 aileyi varlıklı ya da orta sınıfa mensup olarak nitelendirebiliriz. Diğer 3 aile yoksul ve son derece dar gelirlidir. Bununla birlikte, eski ve yeni haritalar dikkatle incelendiğinde Furen köyünden ve yakınlarından 3 akarsuyun geçtiği anlaşılmaktadır. Tarlaların su taşkınına uğraması ya da çayırlık olması mümkündür. Bu tespitler şu tahmine yol açmaktadır: Çerkes aileleri bol hasat elde etme hususunda da toprak büyüklüğü açısından önemli problemler yaşamamışlardır. Belki doğal afetlerden ya da toprağın veriminden kaynaklanan bazı sorunlarla karşılaşmış olabilirler.

1867 emlak defterinde kayıtlı Üçbunar Çerkeslerinin 45’i 1871 öşür defterinde de geçmektedir. Aralarından biri 120 dönümlük toprağa sahiptir ve 1871 yılında çok zengindir. Bu gruba mensup olan diğer 5 toprak sahibi 60 dönümlük tarlaları işlemektedir. Aynı zamanda, 60 dönümlük tarlalara sahip birkaç aile 1871 yılında hububat fazlası elde edememiş, yoksul ve son derece dar gelirli sınıfına girmiştir. 30 dönümlük araziler verilen 12 aile 1871 yıında orta sınıfa, varlıklılar ve zenginler gruplarına mensuptur. Bu örnekler (BMK, Or. B., Oryahovo, $16 / 2 ; 32 A / 98)$ toprak büyüklüğünün Üçbunar köyündeki Çerkeslerin tarımsal faaliyetlerini etkilemediğini ortaya koymaktadır. Herhalde bazı Çerkes aileleri topraklarının bir kısmını çayırlık olarak ayırmakta ya da kiraya vermektedir. Toprak büyüklüğü ve 1871 yılında hasat edilen mahsul göz önüne alınarak bazı ailelerin girişken ve çalışkan, bazılarının tembel olarak nitelenmesi yanlış bir yaklaşım olacaktır. 0 zamanki hayat şartlarındaki ani değişimler toprak sahibini gündelikçiye dönüştürebiliyordu.

Gerek Furen ve Üçbunar, gerekse Sovat köyündeki Çerkes aileleri hububat fazlasından elde ettikleri geliri nereye harcamaktaydı? Nakdî 
vergilerini ödedikten sonra bazıları elbise, ev eşyaları ve tarım aletleri, bazıları ise silah ve at satın alabilirdi. Birçok aile Nisan 1873 yangınında kaybettikleri evlerini yeniden yapmaya çalışmış ya da hububatın bir miktarını tuttukları gündelikçilere aynî olarak vermiş olabilir. Böylece tarım ürünlerinden kazanılan gelirler çok çabuk harcanmış olacaktı ve Çerkes aileleri tüm köylüler gibi yine hasat edecekleri mahsule bel bağlayacaklardı.

\section{Sonuç}

Hesaplanan hububat yeterliliği ve fazlalığına bağlı olarak ileri sürülen tüm tahminler ve sonuçlar problemli olarak değerlendirilebilir. Ama İvraca ve Rahova kazalarına yerleştirilen Çerkes topluluklarını anlatan Osmanlı belgeleri ancak matematik yöntemlerle incelenerek göç sonrasının gündelik yaşamlarına ve ekonomik etkinliklerine ışık tutan tek kaynaktır. İvraca ve Rahova kazalarında toplam 19 Çerkes yerleşim yeri bulunmaktaydı. Yerleşimleri akrabalık prensiplerine bağı olan Çerkes ailelerinden \%43-44'ü 1877/1878 Osmanlı-Rus Savaşı'na kadar Rahova kazasındaki köylerde yaşadı. Bir ailede ortalama nüfus 3.3 kişiyken, 8 kişilik ailelere de rastlanıyordu. Ailelerin çoğu 2 çocuğa sahipti, 4-5 çocuklu aileler ise istisnaydı. Hem kız ve erkek çocuklar hem de kadınlar ve erkekler arasında nedenleri tespit edilemeyen önemli bir oransızlık görülüyordu.

Ovalık Rahova kazasından farklı olarak İvraca kazası dağlık, toprakları taşlık ve sürülmemiş arazileri tarıma elverişli değildi. Dolayısıyla İvraca kazasına daha çok hayvancılıkla geçinen Çerkes aileleri yerleştirilmişti ve çoğu Rahova kazasında günlük işlerde çalışıyordu. Çerkesler arazinin büyüklüğü açısından önemli sorunlar yaşamadılar. Elde ettikleri hububat miktarı doğal afetler, toprağın kalitesi, mevcut iş gücü, intiyaç gibi faktörler tarafından belirleniyordu. Muhtemelen Rahova kazasındaki Çerkes ailelerinin çoğu, 4 kişilik bir ailenin yıllık gıda ihtiyacını karşılayabiliyordu. Bazıları hasat ettikleri hububatın bir kısmını yerel pazara sunabiliyordu. Tarım ürünlerinden kazanılan para rüşdiye mekteplerindeki yardımcı öğretmenlerin maaşlarından düşüktü ve hızlıca giyecek, ev eşyası ve tarım aletlerine harcanıyordu. Bu nedenle Çerkes aileleri, tüm köylüler gibi topraktan elde ettikleri ürünlere bağımlıydılar. 
Tablo 1 1876'da Çerkes Evlerinin Maliyeti

\begin{tabular}{|l|l|l|l|l|l|l|l|l|}
\hline $\begin{array}{l}\text { Guruş / } \\
\text { Köy }\end{array}$ & 250 & 500 & 750 & 1000 & 1250 & 1500 & 2000 & 2500 \\
\hline Üçbunar & 24 & 36 & & & & & & 2 \\
\hline Sovat & 1 & 302 & & 14 & & 1 & & \\
\hline Tırnava & 2 & 16 & 7 & 13 & 7 & 4 & 2 & \\
\hline Toplam & 27 & 354 & 7 & 27 & 7 & 5 & 2 & 2 \\
\hline
\end{tabular}

Tablo 2 Çerkes Köylerindeki Aile Sayısı

\begin{tabular}{|l|l|l|l|l|}
\hline Köy & $\begin{array}{l}1867 \text { Emlak }^{20} \\
\text { Defterleri }^{20}\end{array}$ & $\begin{array}{l}1871 \text { Öşür } \\
\text { Defterleri }^{21}\end{array}$ & $\begin{array}{l}1875 \text { Iane } \\
\text { Defterleri }^{22}\end{array}$ & $\begin{array}{l}1876 \\
\text { Yoklama }^{\text {Defterleri }^{23}}\end{array}$ \\
\hline Sovat & 300 & 306 & & En az 316 \\
\hline Bregare & 224 & & & \\
\hline Üçbunar & 89 & 64 & En az 53 & En az 62 \\
\hline Tırnava & 56 & & & En az 51 \\
\hline Bırzine & 51 & & & \\
\hline Furen & 36 & 29 & & \\
\hline Maligrad & & & En az 71 & \\
\hline Beli brod & & & En az 39 & \\
\hline
\end{tabular}

${ }^{20}$ BMK, Or. B., Oryahovo 16/2; F. 32, gömlek 124, 470, 473-474, 476; F. 32A, gömlek 176.

${ }^{21}$ BMK, Or. B., F. 32,gömlek 15;F. 32A, gömlek 98, 381.

${ }^{22}$ BMK, Or. B., F. 32,gömlek 856-857, 798.

${ }^{23}$ BMK, Or. B., Oryahovo 14/7. 
Tablo 3 Sovat Köyünde Yaşayan Çerkes Aileleri

\begin{tabular}{|c|c|}
\hline Sadece 1867 emlak defterinde kayıtlı aileler ${ }^{24}$ & 127 \\
\hline 1867 defterinde adları ve emlakları eksik olan aileler & 65 \\
\hline Sadece 1871 öşür defterinde kayıtlı aileler ${ }^{25}$ & 155 \\
\hline Sadece 1876 yoklama defterinde kayıtlı aileler ${ }^{26}$ & 196 \\
\hline 1867 ve 1871 defterlerinde geçen aileler & 41 \\
\hline 1867,1871 ve 1876 defterlerinde geçen aileler & 57 \\
\hline 1867 ve 1876 defterlerinde geçen aileler & 10 \\
\hline 1871 ve 1876 defterlerinde geçen aileler & 53 \\
\hline
\end{tabular}

Tablo 4 Üçbunar Köyünde Yaşayan Çerkes Aileleri

\begin{tabular}{|c|c|}
\hline Sadece 1867 defterinde kayıtlı aileler ${ }^{27}$ & 34 \\
\hline Sadece 1871 defterinde kayıtlı aileler ${ }^{28}$ & 8 \\
\hline Sadece 1875 defterinde kayıtlı aileler ${ }^{29}$ & 18 \\
\hline Sadece 1876 defterinde kayıtlı aileler ${ }^{30}$ & 10 \\
\hline 1867 ve 1871 defterlerinde geçen aileler & 7 \\
\hline 1867 ve 1875 defterlerinde geçen aileler & 3 \\
\hline 1867 ve 1876 defterlerinde geçen aileler & 4 \\
\hline 1867,1871 ve 1875 defterlerinde geçen aileler & 4 \\
\hline 1867,1871 ve 1876 defterlerinde geçen aileler & 17 \\
\hline $1867,1871,1875$ ve 1876 defterlerinde geçen aileler & 18 \\
\hline 1867,1875 ve1876 defterlerinde geçen aileler & 2 \\
\hline 1871ve 1876 defterlerinde geçen aileler & 7 \\
\hline 1871 ve 1875 defterlerinde geçen aileler & 3 \\
\hline 1875 ve 1876 defterlerinde geçen aileler & 4 \\
\hline
\end{tabular}

\footnotetext{
${ }^{24}$ BMK, Or. B., F. 32A, gömlek176.

${ }^{25}$ BMK, Or. B., F. 32, gömlek 15.

${ }^{26}$ BMK, Or. B., Oryahovo 14/7.

${ }^{27}$ BMK, Or. B., Oryahovo 16/2.

${ }^{28}$ BMK, Or. B., F. 32A, gömlek 98.

${ }^{29}$ BMK, Or. B., F. 32, gömlek 857.

${ }^{30}$ BMK, Or. B., Oryahovo 14/7.
} 
Tablo 5 Tırnava Köyünde Yaşayan Çerkes Aileleri

\begin{tabular}{|l|l|}
\hline Sadece 1867 defterinde kayıtlı aileler $^{31}$ & 21 \\
\hline 1867 ve 1876 defterlerinde geçen aileler & 35 \\
\hline Sadece 1876 defterinde kayıtlı aileler & 32 \\
\hline
\end{tabular}

Tablo 660 Gün İçinde Tüketilecek Hububat Yardımına Göre Ailelerin Kişi Sayısı

\begin{tabular}{|l|l|l|l|l|l|l|}
\hline Kişi & $\begin{array}{l}\text { Mısır Miktarı } \\
(\mathrm{kg})\end{array}$ & Üçbunar & Maligrad & Tırnava & $\begin{array}{l}\text { Beli } \\
\text { brod }\end{array}$ & Toplam \\
\hline 1 & $64-76$ & & & 2 & 1 & 3 \\
\hline 2 & $108-143$ & 36 & 5 & 4 & 5 & 50 \\
\hline 3 & $145-186$ & & 6 & & 4 & 10 \\
\hline 4 & $192-236$ & 4 & 13 & & 3 & 20 \\
\hline 5 & $243-281$ & 4 & 17 & 7 & 34 & 62 \\
\hline 6 & $294-332$ & & 7 & 2 & & 9 \\
\hline 7 & $337-372$ & & 11 & 1 & & 12 \\
\hline 8 & $398-431$ & & 8 & & 1 & 9 \\
\hline 9 & 433 kilo & & 1 & & & 1 \\
\hline 10 & $504-522$ & & 1 & 1 & 1 & 3 \\
\hline 13 & 637 & & & & 1 & 1 \\
\hline
\end{tabular}

Tablo 7 Ekim 1873'te Hayreddin Köyünde Yaşayan Çerkes Ailelerinin Kişi Sayısı

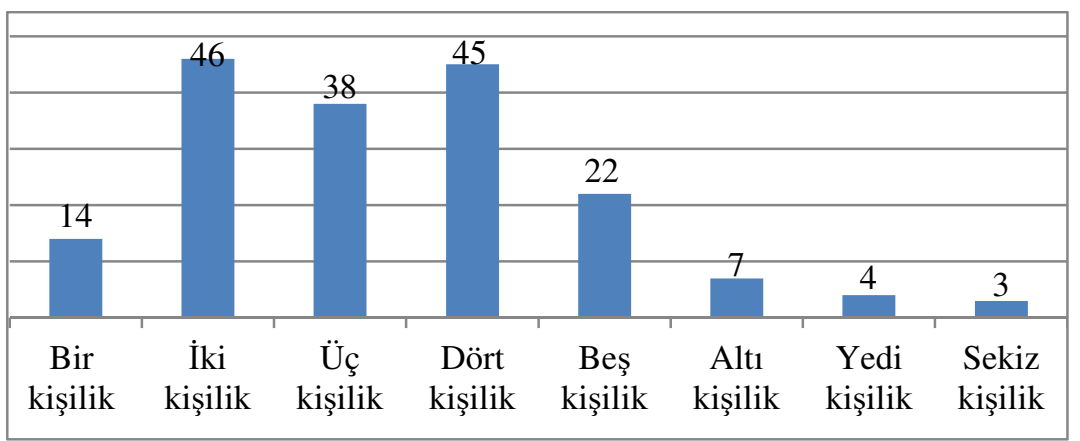

\footnotetext{
${ }^{31}$ BMK, Or. B.,F. 32, gömlek 476.

32 BMK, Or. B., Oryahovo 14/7.
} 
Tablo 8 Hayreddin Köyündeki Çerkes Ailelerinin Yapısı

\begin{tabular}{|c|c|c|}
\hline $\begin{array}{l}\text { Hane ya da } \\
\text { Ailede } \\
\text { Sayısı }\end{array}$ & Hane ya da Aile Tipi & $\begin{array}{l}\text { Kişi } \\
\text { Sayısı }\end{array}$ \\
\hline Bir & $\begin{array}{l}\text { Tek başına yaşayan erkekler ya da } \\
\text { kadınlar }\end{array}$ & 14 \\
\hline \multirow[t]{4}{*}{ íki } & Bekar erkek ve cariye & 1 \\
\hline & ìki kardeş & 4 \\
\hline & Karı ve koca & 34 \\
\hline & Anne ve oğlu & 7 \\
\hline \multirow[t]{5}{*}{ Üç } & Karı koca ve çocuğu & 27 \\
\hline & Karı koca ve aile reisinin annesi & 3 \\
\hline & Anne ve 2 oğlu & 6 \\
\hline & 3 Kardeş & 1 \\
\hline & Baba ve 2 öksüz çocuğu & 1 \\
\hline \multirow[t]{8}{*}{ Dört } & Karı koca ve 2 çocuğu & 32 \\
\hline & $\begin{array}{l}\text { Baba,öksüz çocuğu, aile reisinin annesi ve } \\
\text { kardeşi }\end{array}$ & 2 \\
\hline & Karı koca, çocuğu ve aile reisinin annesi & 4 \\
\hline & Karı koca, çocuğu ve aile reisinin kardeşi & 3 \\
\hline & Karı koca, oğlu ve eşi & 1 \\
\hline & Karı koca, aile reisinin 2 kardeşi & 1 \\
\hline & Karı koca, aile reisinin annesi ve kardeşi & 1 \\
\hline & 4 Kardeş & 1 \\
\hline \multirow[t]{6}{*}{ Beş } & Karı koca ve 3 çocuğu & 17 \\
\hline & Karı koca, 2 çocuğu ve aile reisinin annesi & 1 \\
\hline & Karı koca, 2 çocuğu ve aile reisinin kardeşi & 1 \\
\hline & $\begin{array}{l}\text { Karı koca, çocuğu, aile reisinin annesi ve } \\
\text { kardeşi }\end{array}$ & 1 \\
\hline & Koca, 2 karısı ve 2 çocuğu & 1 \\
\hline & $\begin{array}{l}\text { Baba, } 2 \text { öksüz çocuğu, aile reisinin annesi } \\
\text { ve kardeşi }\end{array}$ & 1 \\
\hline \multirow[t]{2}{*}{ Altı } & Karı koca ve 4 çocuğu & 5 \\
\hline & Koca, 2 karısı ve 3 çocuğu & 2 \\
\hline
\end{tabular}




\begin{tabular}{|l|l|l|}
\hline \multirow{3}{*}{ Yedi } & Karı koca ve 5 çocuğu & 2 \\
\cline { 2 - 3 } & Karı koca, 4çocuğu ve aile reisinin kardeşi & 1 \\
\cline { 2 - 3 } & Karı koca, 4çocuğu, aile reisinin annesi & 1 \\
\hline \multirow{2}{*}{ Sekiz } & Koca, 2 karısı ve 5 çocuğu & 2 \\
\cline { 2 - 3 } & Koca, 2 karısı, 4 çocuğu ve cariye & 1 \\
\hline
\end{tabular}

Tablo 9 Akrabalık ilişkileri

\begin{tabular}{|l|l|l|}
\hline A: & $\begin{array}{l}\text { Karı koca (dede, } \\
\text { nine)No 160 }\end{array}$ & \\
\hline $\begin{array}{l}\text { Karı koca (oğlu, eşi) ve } \\
2 \text { çocuğu, No 141 }\end{array}$ & $\begin{array}{l}\text { Karı koca (oğlu, eşi) } \\
\text { ve 2 erkek çocuğu, } \\
\text { No 84 }\end{array}$ & $\begin{array}{l}\text { Karı koca (oğlu, eşi) } \\
\text { ve 4 çocuğu, No 70 }\end{array}$ \\
\hline $\begin{array}{l}\text { Evlenmiş üçüncü oğlu } \\
\text { ve eşi, No 142 }\end{array}$ & & \\
\hline
\end{tabular}

\begin{tabular}{|l|l|l|}
\hline B: & Koca karı (no. 153) & \\
\hline $\begin{array}{l}\text { Karı koca (oğlu, eşi) } \\
\text { No 32 }\end{array}$ & $\begin{array}{l}\text { Karı koca (oğlu, eşi) } \\
\text { No 31 }\end{array}$ \\
\hline
\end{tabular}

\begin{tabular}{|l|l|l|l|l|}
\hline C: & $\begin{array}{l}\text { Karı koca } \\
\text { (dede, nine) } \\
\text { ve oğlu, No } \\
139\end{array}$ & \multicolumn{3}{|l|}{} \\
\hline $\begin{array}{l}\text { Karı koca } \\
\text { (oğlu, eşi) }\end{array}$ & $\begin{array}{l}\text { Karı koca } \\
\text { (oğlu, eşi) } \\
\text { ve2 çocuğu, } \\
\text { ve2 çocuğu, } \\
\text { No } 67\end{array}$ & & $\begin{array}{l}\text { Bekar } \\
\text { oğlu, No } \\
69\end{array}$ & $\begin{array}{l}\text { Karı koca } \\
\text { (oğlu, eşi) } \\
\text { ve r 3 } \\
\text { çocuğu, No } \\
134\end{array}$ \\
\hline
\end{tabular}

\begin{tabular}{|l|l|l|l|l|}
\hline Ç: & $\begin{array}{l}\text { Koca (dede), } \\
\text { ikinci karısı } \\
\text { (?), 3 çocuğu } \\
\text { No 140 }\end{array}$ & \multicolumn{2}{|l}{} \\
\hline $\begin{array}{l}\text { Karı koca } \\
\text { (oğlu, eşi) }\end{array}$ & $\begin{array}{l}\text { Karı koca } \\
\text { (oğlu, eşi), }\end{array}$ & $\begin{array}{l}\text { Bekar oğlu, } \\
\text { No 83 }\end{array}$ & $\begin{array}{l}\text { Karı koca } \\
\text { (oğlu, } \\
\text { ve2 çocuğu, } \\
\text { No 81 }\end{array}$ & $\begin{array}{l}\text { Norı), No koca (oğlu, eşi) } \\
\text { bekar erkek kardeş } \\
\text { ve anne (birinci eşi } \\
\text { ?), No 115 }\end{array}$ \\
\hline
\end{tabular}


D:

\begin{tabular}{|l|l|l|l|l|}
\hline $\begin{array}{l}\text { Karı koca, 4 } \\
\text { çocuğu, No 174 }\end{array}$ & + & $\begin{array}{l}\text { Koca (kardeş) karı, } \\
\text { çocuğu ve bekar bir } \\
\text { kardeşi, No 76 }\end{array}$ & + & $\begin{array}{l}\text { Diğer 2 kardeşi, } \\
\text { No 77 }\end{array}$ \\
\hline
\end{tabular}

E:

\begin{tabular}{|c|c|c|}
\hline Karı koca (ikinci eşi & 2 çocuğu, No 117 & \multirow[t]{2}{*}{\begin{tabular}{l|l} 
Koca (kardeş) \\
karı ve çocuğu, \\
No 116
\end{tabular}} \\
\hline$\downarrow$ & & \\
\hline $\begin{array}{l}\text { Karı koca (oğlu, } \\
\text { eşi) ve } 2 \text { çocuğu, } \\
\text { No } 101\end{array}$ & $\begin{array}{l}\text { Karı koca (oğlu, } \\
\text { eşi) ve çocuğu, } \\
\text { No } 102\end{array}$ & $\begin{array}{l}\text { Anne (birinci eşi ?) } \\
\text { ve oğlu, No } 103\end{array}$ \\
\hline
\end{tabular}

F:

\begin{tabular}{|l|l|}
\hline Karı koca ve çocuğu, No 105 & $+\begin{array}{l}\text { Bekar kardeş, No } \\
98\end{array}$ \\
\hline $\begin{array}{l}\text { Karı koca (oğlu, eşi) ve } 4 \\
\text { çocuğu, No 47 }\end{array}$ & $+\begin{array}{l}\text { Karı koca ve başka } \\
\text { bir kişi, No } 97\end{array}$ \\
\hline
\end{tabular}

G:

\begin{tabular}{|c|c|c|c|c|c|c|}
\hline $\begin{array}{l}\text { Karı koca } \\
\text { (büyük dede ve } \\
\text { nine / baba, } \\
\text { anne), No } 122\end{array}$ & + & $\begin{array}{l}\text { Koca } \\
\text { (kardeş / } \\
\text { amca) karı } \\
\text { ve çocuğu, } \\
\text { No } 121\end{array}$ & + & $\begin{array}{lr}\begin{array}{lr}\text { Koca } \\
\text { (kardeş } \\
\text { amca) } \\
\text { ve }\end{array} \\
\text { çocuğu, } \\
120\end{array}$ & + & $\begin{array}{l}\text { Koca } \\
\text { (kardeş / } \\
\text { amca) karı } \\
\text { ve } \\
\text { çocuğu, No } \\
123\end{array}$ \\
\hline
\end{tabular}

\begin{tabular}{|l|l|}
\hline $\begin{array}{l}\text { Karı koca (dede, nine) } \\
\text { ve çocuğu, No } 171\end{array}$ & $+\begin{array}{l}\text { Koca (kardeş), 2 karı } \\
\text { ve 2 çocuğu, No 172 }\end{array}$ \\
\hline $\begin{array}{l}\text { Karı koca (oğlu, eşi), No } \\
75\end{array}$ & $+\begin{array}{l}\text { Koca (kardeş) karı ve } \\
\text { çocuğu, No 108 }\end{array}$ \\
\hline
\end{tabular}


Tablo 10a Tarla Büyüklüğüne Göre Ailelerin Dağılımı (Rahova kazasında)

\begin{tabular}{|l|l|l|l|l|l|l|l|l|l|l|}
\hline $\begin{array}{l}\text { Dönüm } \\
\text { / Köy }\end{array}$ & 200 & 150 & 120 & 100 & 90 & 60 & 50 & 30 & 0 & $\begin{array}{l}\text { Tedarik } \\
\text { edilen çift } \\
\text { sürme } \\
\text { hayvanları }\end{array}$ \\
\hline Sovat & & & & & 2 & 13 & & 202 & 18 & $\begin{array}{l}15 \text { çift } \\
\text { öküz, 2 inek }\end{array}$ \\
\hline Bregare & 1 & 5 & & 102 & & & 110 & & 6 & $\begin{array}{l}95 \text { çift } \\
\text { öküz, 25 } \\
\text { inek }\end{array}$ \\
\hline Üçbunar & & & 1 & & & 9 & & 59 & & 32 çift öküz \\
\hline Tırnava & & & & & & & & 52 & & --- \\
\hline Bırzine & & & & & & & & 47 & & 8 çift öküz \\
\hline Furen & & & & & & & & 22 & & 14 çift öküz \\
\hline Toplam & 1 & 5 & 1 & 102 & & 70 & 110 & 382 & 24 & \\
\hline
\end{tabular}

Tablo 10b Tarla Büyüklüğüne Göre Ailelerin Dağılımı

\begin{tabular}{|l|l|l|l|l|l|l|}
\hline $\begin{array}{l}\text { Dönüm / } \\
\text { Köy }\end{array}$ & $\begin{array}{l}30 \text { Dönümden } \\
\text { Fazla }\end{array}$ & $\begin{array}{l}29- \\
25\end{array}$ & $\begin{array}{l}24- \\
20\end{array}$ & $\begin{array}{l}19- \\
15\end{array}$ & $\begin{array}{l}14- \\
10\end{array}$ & $\begin{array}{l}9- \\
1\end{array}$ \\
\hline $\begin{array}{l}\text { Kamenno } \\
\text { Pole }\end{array}$ & 1 & 2 & 4 & 16 & 3 & \\
\hline Meciye & & & 68 & & & \\
\hline Bukovets & 3 & 6 & 13 & 8 & 7 & 3 \\
\hline Toplam & 4 & 8 & 85 & 24 & 10 & 3 \\
\hline
\end{tabular}


Tablo 11 Furen Köyünde Yaşayan Çerkes Ailelerinin Sosyal

\section{Dağılımı}



Tablo 12 Üçbunar Köyünde Yaşayan Ailelerinin Sosyal Dağılımı

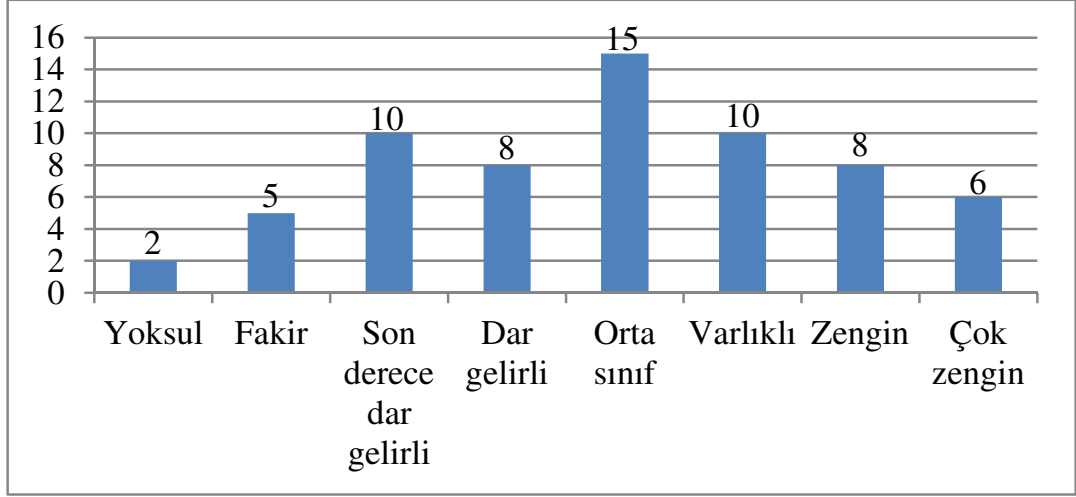

Tablo 13: Sovat Köyünde Yaşayan Çerkes Ailelerin Sosyal Dağılımı

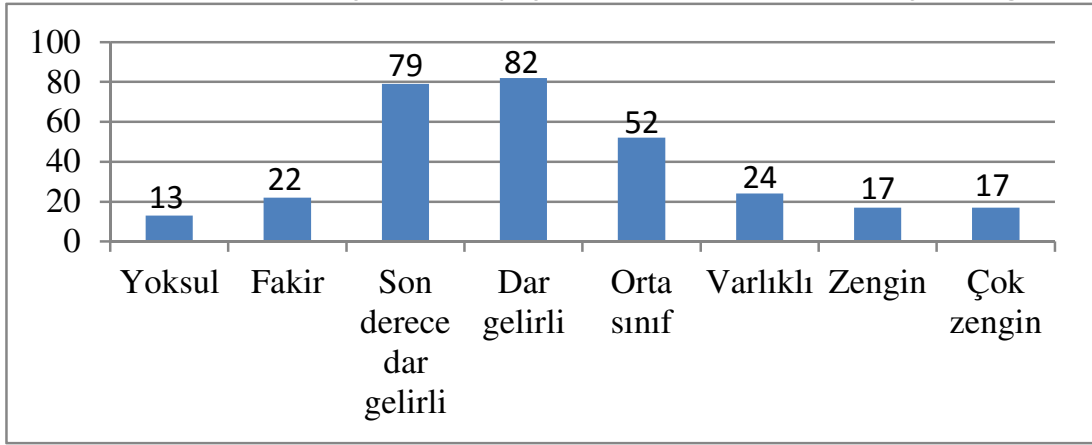




\section{KAYNAKÇA}

\section{Arşiv Belgeleri}

Vidin 1/39, 5/29, 51/109; Oryahovo 13/15, 14/7, 16/2, 16/3, 16/14; İvraca 18/4,18/7, 18/8; F. 26, gömlek 217-219, 11136, 11541; F. 27, gömlek 695; F. 29, gömlek 105, 178, 498, 605-606, 825, 843; F. 31, gömlek 337; F. 32, gömlek 15, 26, 124, 470, 473-474, 476, 611, 773, 798, 856-857, 961, 965, 990, 1008, 1096; F. 181, gömlek 487; F. 29A, gömlek 202, 275-276, 440; F. 32A, gömlek 98, 171, 176, 284, 291, 381, 444-451, 616, 799-800, 850, 1018.

\section{Gazeteler}

Tasvir-i Efkâr, No. 9, 29 Temmuz 1862; No. 11, Ağustos 1862; No. 13, 11 Ağustos 1862; No. 41, 17 Kasım 1862; No. 59, 19 Ocak 1863; No. 90, 8 Mayıs 1863; No. 108, 10 Temmuz 1863; No. 117, 10 Ağustos 1863; No. 151, 7 Aralık 1863; No. 153, 14 Aralık 1863; No. 160, 7 Ocak 1864.

Tsarigradski vestnik, Yıl. 6, No. 271-272, 14-21 Nisan 1856.

Tuna, No. 23, 4 Ağustos 1865; No. 57. 16 Mart 1866; No. 99, 14 Ağustos 1866; No. 631-652, 28 Kasım 1871 - 20 Şubat 1872;

Vek, YIl 2, No. 10, 8 Mart 1875;

İztoçno Vreme, Yıl 6, No. 15, 20 Nisan 1874.

\section{Araştırma ve incelemeler}

Aydemir, i. (1988), Kuzey Kafkasyalıların Göç Tarihi, Gelişim Printing House: Ankara.

Andreyev, S. (ed.) (1993), Opis na osmano-turski dokumenti za zanayatite i tırgoviyata (XVI-XIXvek), Sofia, MK "Kiril ve Metodiy".

Bayraktar, H. (2007), “Kırım ve Kafkasya'dan Adana Vilayeti'ne Yapılan Göç ve İskânlar (1865-1907)”, Türkiyat Araştırmalari Dergisi, 22, 405-434.

Berber, F. (2011), “19. Yüzyılda Kafkasya'dan Anadolu'ya Yapılan Göçler”, Karadeniz Araştırmaları 31, 17-49.

Bice, H. (1991), Kafkasya'dan Anadolu'ya Göçler, Türkiye Diyanet Vakfı Yayınları: Ankara.

Bulgaristan Haritası, (1998), Ölçek 1:530 000, Datamap-Evropa OOD.

Cox, P.R. (1976), Demography, Cambridge University Press: Cambridge.

Çiçek, N. (2009), "Talihsiz Çerkeslere İngiliz Peksimeti: İngiliz Arşiv Belgelerinde Büyük Çerkes Göçü (Şubat 1864-Mayıs 1865)", Ankara Üniversitesi Siyasal Bilgiler Fakültesi Dergisi, 64/1, 57-88.

Dobreva, M. (2013), "Settlement and Integration of Circassians in the Danube Vilayet (Prelimary Notes)", Ankara Üniversitesi Osmanlı Tarihi Araştırma ve Uygulama Merkezi Dergisi, 33, 1-30. 
Dobreva, M. (2015), "Remarks on the Circassian Settlements in the kaza of Lom and of Belogradçik", in Petar Parvanov (ed.), Prouçvaniya po stopanska istoriya $i$ istoriya na sotsialno-ikonomiçeskata sfera $v$ Yugozapadna Bılgaria. Blagoevgrad, Ui “NeofitRilski”, 106-130.

Dorev, P. (ed.) (1940), Dokumenti za bılgarskata istoriya, 3, Dokumenti iz turskite dırjavni arhivi 1564 -1909, BAN: Sofia.

Emecen, F. (1993), “Çift Resmi”, İslam Ansiklopedisi, İstanbul, 8, 309-310.

Gutheil, D. (2003), "The Circassian Sürgün”, Ab Imperio 2, 139-168.

Güneş, M. (2014), "Kafkasya Muhacirlerinin Karahisar-i Sahib'de İskânı ve Karşılaşılan Sorunlar (1861-1895)", Tarih Okulu Dergisi (TOD), 7/18, 421-452.

Hacısalihoğlu, M, (ed.) (2014), 1864 Kafkas Tehciri. Kafkasya'da Rus Kolonizasyonu, Savaş ve Sürgün, BALKAR \& IRCICA: İstanbul.

İkonomov, T. (1885), Protokoli na Berlinskiya kongres, Sofia.

Kanitz, F. (1880), Original-Karte von Donau-Bulgarien und dem Balkan nach seinen eigenen Reise-Aufnahmeninden Jahren 1870-1874 ausgeführt. Maßstab 1:420 000, zweiteAuflage.

Kara, A. (2013) “XIX. Yüzyılda Çorum'da Göçmenlerin Yerleştirilmesi ve Yaşanan Sorunlar", Turkish Studies, 8, 333-344.

Karataş, Ö. (2012), “XIX. Yüzyılın İkinci Yarısında Osmanlı Devleti’ne İskan Olunan Çerkes Toplumunda Sosyal Sınıflaşma ve Kölelik", Avrasya incelemeleri Dergisi (AVID), 1/2, 99-138.

Karpat, K. (2002), "The Status of the Muslims under European Rule: The Eviction and Settlement of the Cerkes", Studies on Ottoman Social and Political History, Selected Articles and Essays, Brill: Leiden, 647-675.

Karpat, K. (2002), “Ottoman Urbanism: The Crimean Emigration to Dobruca and the Founding of Mecidiyye, 1856-1878", Studies on Ottoman Social and Political History, Selected Articles and Essays, Brill: Leiden, 202234.

Keleş, E. (2009), “Kırım Savaşı'ndan Sonra Gelen Muhacirlerin Menteşe Sancağı'nda İskânı", Turkish Studies, 4/8, 1166-1188.

Mitkov, T. (1961), Telkiev, G., Tsarevitsa. Rıkovodstvo za krıjoçnitsi po rastenevidstvo, Zemizdat, Sofia.

Miçev, N. (2005), Reçnik na imenata i statuta na naselenite mesta $v$ Bılgaria 1878 - 2004. İztok-Zapad, Sofia.

Muçinov, V. (2013), Migratsionna politika na Osmankata imperiya v bılgarskite zemi prez XIX vek (do 1878 godina), Regaliya 6, Sofia.

Ovsyani, N. R. (1906), Sbornik materialov grajdanskomu upravleniyu okkupatsii Bolgarii v 1877-78-79 gg., Vıpusk 5, S. Peterburg.

Pul, A. (2011), "Trabzon ve Samsun Limanları Üzerinden Kafkasya Muhacirlerinin İskânı (1860-1864)”, Sürgün, 21 Mayıs 1864, Ankara, 181-207. 
Salname-i Vilayet-i Tuna, (1873), Defa 6, Vilayet Matbaası: Rusçuk.

Saydam, A. (2010), Kırım ve Kafkas Göçleri (1856-1876), Türk Tarih Kurumu: Ankara.

Şaşmaz, M. (1999), "Immigration and Settlement of Circassians in the Ottoman Empire on British Documents, 1857-1864", OTAM 9, Ankara, 331366.

Todorova, M. (2006), Balkan Family Sturcture and the European Pattern. Demographic Development in Ottoman Bulgaria, Central European University Press: Budapest.

Toledano, E. R. (1994, 2001), Osmanlı Köle Ticareti 1840-1890, Türkiye Ekonomik ve Toplumsal Tarih Vakfı: İstanbul.

Tutum, C. (1993), "1864 Göçü İle İlgili Bazı Belgeler”, Çerkeslerin Sürgünü (21 Mayıs 1864), Kuzey Kafkasya Kültür Derneği, Ankara, 3-41; 7-51.

Winch, T. (2007), Growing Food. A Guide to Food Production, Springer: Dordrecht.

Yel, S., Gündüz, A. (2008), “19. Yüzyılda Çarlık Rusyası'nın Çerkesleri Sürgün Etmesi ve Uzunyaylaya Yerleştirilmeleri, 1860-1865", Turkish Studies 3/4, 949-983.

www.vostlit.info (2015), "Vostoçnaya literatura. Srednovekovıye istoriçeskiye istoçniki Vostoka i Zapada." 